\title{
Factors Affecting Hotelier Job Performance - A study of Entry Level Position Staff in Three-Star Hotels
}

\author{
Maher Fouad Hossny
}

\begin{abstract}
This study explores the factors affecting job performance in three-star hotels in Greater Cairo, Egypt. Based on the literature discussed, six factors were considered as the vital components influencing employees' performance that should be examined. The research question depends on which factors have a concurrent and partial effect on employee performance. The finding revealed that being male has a significant influence on four of the organizational factors that affect employee performance. These factors are commitment; empowerment; promotion justices; salaries and compensations. While, being female gender has a significant influence on three of organizational factors that affect employee performance. These factors are displayed as: promotion justices; commitment; salaries and compensations. In addition, the variable of work experience has no significant influence on all the organizational factors that affect employee performance. The value of the determination coefficient test was $63 \%$, which means that linear regression explains the variance in the data, while the remaining of $37 \%$ is described by other factors. Moreover, the F test showed that training, empowerment, and salaries have partial effect on employee performance, while managerial standards, commitment and promotion variables have no effect on employee performance.
\end{abstract}

\section{Keywords}

Staff, performance, Managerial standards, empowerment

\section{Introduction}

Staff performance is varied dimensions-build intended to accomplish goals and has a solid connect to vital objectives of an organization (Mwita, 2000). Staff performance could be the impetus driving hotels to become more proficient. The association between employee inspiration and performance could influence hierarchical viability (Netke, 2013). Van De Voorde and Beijer (2014) recommended that HR management was an essential factor in staff performance, fairness and justices', training and development, and employee stratification. 


\section{Factors Affecting Hotelier Job Performance - A study of Entry Level Position Staff in Three-Star Hotels}

Motowildo (2003, page number for direct quote) explained that:, "Employment performance is characterized as the aggregate anticipated that esteem would the organization of the discrete behavioral scenes that an individual does over a standard period." Accordingly, the performance is characterized by the activities judgmental and evaluative procedures. For each hotel, the most essential component is the staff's performance in light of the fact that the achievement or disappointment of an organization relies upon the performance of a worker. Sandler and Keefe (2004) referred to the most important factors that affect employee performance are managerial standards, commitment, training and development, empowerment, promotional fairness, salaries and compensations. To get the maximum performance from entry level position staff, management need to provide them with the tools they need to succeed

\section{Literature}

\subsection{Performance}

Performance is defined as a level of accomplishment of the tasks in the work place that develops staff occupation (Cascio, 2015). Sandler and Keefe (2004) who have diverse musings about performance. Most researchers have utilized the term performance to express the scope of estimations of value-based proficiency and information and yield effectiveness. Swarnalatha and Sureshkrishna (2014) suggested that setting up the workforce with great employee job performance turns out to be exceptionally earnest and essential with the key components to make great staff performances, for example, career development, team work, relationship at work, benefit and advantage, working conditions, work stress and employment satisfaction. A study by Colquitt et al. (2014) explained that employee performance is characterized as the estimation of the arrangement of worker practices that contribute, either emphatically or adversely to authoritative objective achievement while task performance are staff behaviours that are straightforwardly engaged with the change of hierarchical assets into the goods or services that the industry produces.

Kahya (2009, page number for direct quote) divided performance into two measurements: "task performance" and "contextual performance." $\mathrm{He}$ recognized task performance as the conduct of the staff that is straightforwardly required in the delivery of merchandise or administration 
exercises given roundabout help to the association's center specialized procedures. Task performance alludes to the capacity of staff to utilize their particular aptitudes and information to help the organization's center specialized procedures. In any case, Werner (2000) clarified the contextual performance as the exertion of staff is not specifically identified with the principal errand work but is still vital. This is because of they frame the association, social, and mental setting that fills in the essential point for assignment exercises and procedures.

\subsubsection{Empowerment}

The first significance of the word empowerment has been alluded to as "approve, or offer power to someone" (Tetteh et al., 2012). Anil Kumar (2012) additionally centered around control as the purpose of empowerment. He defined empowerment as doling out basic leadership power to staff and making them in charge of the outcomes. Anil Kumar mentioned that trusted power could empower the exchanging of control with appropriate training and changing over an entire organization to empowerment model. It might give a specific level of expert to certain endowed workers with the goal that the workers can settle on their own basic leadership to finish the undertaking. It implies that the employees have adequate flexibility to receive any techniques or thoughts, which he or she considers compelling in playing out a given undertaking.

A study by Braimah (2016) indicated that empowerment was observed to be a noteworthy driver of staff responsibility in the hospitality industry. Staff empowerment decidedly and essentially affected worker responsibility. The results of his study found that management ought to enable staff to utilize their caution and take initiatives. This can make the employee feel pertinent and needed by the lodging, accordingly, building up his or her strong feeling of commitment to the hotel.

Kim and Lee (2013) explained that employee empowerment as enhancing profitability and lessened cost structure by guaranteeing inventiveness and advancements. As the responsibility increases, the productivity of the employees additionally increases and, along these lines, they can convey quality service to the clients. The empowered employees

additionally endeavor to go for broke in order to look for more prominent opportunities to succeed. Employee empowerment further causes staff to use imaginative thoughts for fulfilling the clients. 


\subsubsection{Training and Development}

Training and development has been recognized to be an imperative factor of hierarchical performance. Training staff successfully is viewed as critical with regards to performance change of employees, since it upgrades employees level and a competency of the firm and it offers help to elevate employees; performance. In this manner, Training turns into an imperative prerequisite in the industry or rather working environment. Without it, employees do not have a firm grasp on their obligations (Elnaga and Imran, 2013). Training and development is fundamentally coordinated at the representative however, its definitive effect goes to the organization, because the end client of its advantage is simply the organization (Raja et al., 2011).

Career development gives advantages to employees participating in job training and different sorts of expert development keeping in mind the end goal to accomplish the better new propelled aptitudes, to assume more prominent liability at work, to enhance their status, to acquire higher pay, all of which is meant to advance their career (SHRM, 2013).

Training can be utilized as a proactive means for creating abilities and aptitude to keep issues from emerging and can be a compelling instrument in tending to any aptitude or performance gaps among staff. Development can be utilized to make answers for working environment issues, before they turn into a worry or after they end up noticeably identifiable issue (Aguinis, 2013). Development is a procedure that strives to fabricate the ability to accomplish and support another coveted express that advantages the association or group and the world around them.

AlBattat and Som (2013) argued that development is a point of view that looks at the present condition, the present state, and helps individuals in a group, in a division and as a feature of an organization to recognize powerful procedures for enhancing performance. In a few circumstances, there may not be anything incorrectly right now; the gathering or supervisor may be looking for approaches to proceed to create and upgrade existing connections and occupational performance. In different circumstances, there might be an identifiable issue or issue that should be tended to the development procedure plans to discover thoughts and arrangements that can viably restore the gathering to a condition of elite. 


\subsection{Salaries and Compensations}

Salary is one of the incitements, which is central; no other motivational strategy or rather impetus comes nearer to it as to its compelling nature (Rynes et al., 2004). Wages have the overwhelming nature to polarize, maintain, and move employees towards achieving superior. Frederick Taylor and his logical administration associate certified that, the most basic factor in motivating the mechanical laborers to accomplish more noteworthy yield is salary (Adeyinka et al., 2007). All associations utilize development, pay, rewards, or different sorts of prizes in order to motivate and push for an abnormal state of exhibitions by their workers (Reena \& Ahmed, 2009).

Murphy (2015) explained that the measure of pay, points of interest, or counterpart's worker got in-kind for activity which employee renders to the organization. Finding the appropriate mix of substantial and impalpable prizes to satisfactorily hold your workers is a hard obligation, so reward can be natural or outward, it can be in type of cash, or reward can be in type of acknowledgment/assertion, for instance, respect validation or best employee of the week or the month.

Salaries and compensations are assuming an essential to attract staff in the hospitality industry. It is an everyday collaboration that makes staff feel that their commitments are valued by the organization. It is perceived for their exceptional qualities and kind of acknowledgment may contribute to high assurance in the workplace. Salaries and compensations or something else ought to be esteemed and should be seen in light of performance (Sekyi et al., 2016)

Randell (2014) reported that when great performance is watched and after that compensated, the odds of it being rehashed are expanded, while poor execution is demoralized or even rebuffed to diminish the shot of it happening once more. Essential issues that assistance guarantee a fruitful reward prepare are prizes can be utilized adequately to upgrade intrigue and execution; rewards don't undermine execution and intrigue; verbal prizes prompt more noteworthy assignment intrigue and execution; substantial prizes improve inspiration when they are offered to individuals for finishing work or for accomplishing or surpassing indicated performance measures. 


\subsection{Managerial Standards}

Managerial standards framework, as indicated by Rudman (2003), is progressively observed as methods for incorporating HRM exercises with the business destinations of the association, where upper-management and HR exercises cooperate to impact individual and aggregate behavior to bolster the association's methodology. Moreover, he additionally focused on that the execution administration framework must fit with the association's way of life. Managerial standards framework is a sort of finished and coordinated cycle for performance management. The accentuation of managerial standards framework is on persistently enhancing hierarchical performance, and this is accomplished through enhanced individual worker performance (Macky and Johnson, 2000).

Macky and Johnson (2000) recommended that managerial standards framework would include the organization communicating its mission/procedures to its workers. The setting of individual performance focuses on meeting the staff member's individual group and at last the association's main goal/strategies. the general evaluation of these people against the concurred set targets; use of the outcomes for recognizable proof of improvement and additionally for managerial choices; and the ceaseless audit of the managerial standards framework to ensure it keeps on adding to the hierarchical execution in a perfect world through conference with employees.

Managerial standard is essential both to managers and to employees. From the businesses imminent, it is imperative to see how your workers add to the destinations of the association. A decent managerial standards framework empowers the association to see how its workers are at present performing. It enables associations to undertake an exhaustive evaluation of the preparation needs of its workers, set advancement designs and gives them the alternative of utilizing the consequence of the performance management procedure to influence an individual compensation. From the employees imminent, the managerial standards handle gives straightforwardness over performance at working environment and can be utilized to survey future vocation advancement prerequisites (Mondy and Noe, 2015). 


\subsection{Commitment}

There are numerous definitions of Commitment. Commitment could be considered as a sort of responsibility that restrict person's through and through freedom. There are many reasons why an association should expand the level of duty in its individuals (Blanchard, 2012). To begin with, authoritative duty is another idea and for the most part is unique in relation to freedom and employment fulfillment. For instance, medical caretakers may like their work, yet they might be disappointed with the healing facility, which they work in it. For this situation, they will search for comparative occupations in other comparable conditions.

\subsection{Promotional Justices}

It has been a culture in hospitality management that when evaluations are done, they are frequently connected with rewards and not to advancement (ref). Additionally, it was likewise watched that evaluation framework in the hospitality management does not generally guarantee that superior workers are dealt with decently concerning both the examination and coming about advancement. In building up an examination framework for associations, management needs to consider both pay increments and advancement (Moulder, 2011).

Taiwo (2010) characterizes justice as equivalent treatment, accepting indistinguishable services and advantages from other individuals. Reasonableness implies different things to different individuals, and our perspective of regardless of whether something is reasonable regularly relies upon the conditions. Skillful staffs are fundamental to the achievement of any association. An essential consider driving fulfillment the work condition is benefit quality

\section{Theoretical Framework}

Figure 1 illustrates the study's theoretical framework for the organizational factors that affect job performance. The independent variables were: managerial standards, commitment, training and development, empowerment, promotion, and salaries and compensations, while the dependent variable was level of job satisfaction and biographical information, such as gender (male or female), and work experience. 


\section{Factors Affecting Hotelier Job Performance - A study of Entry Level Position Staff in Three-Star Hotels}

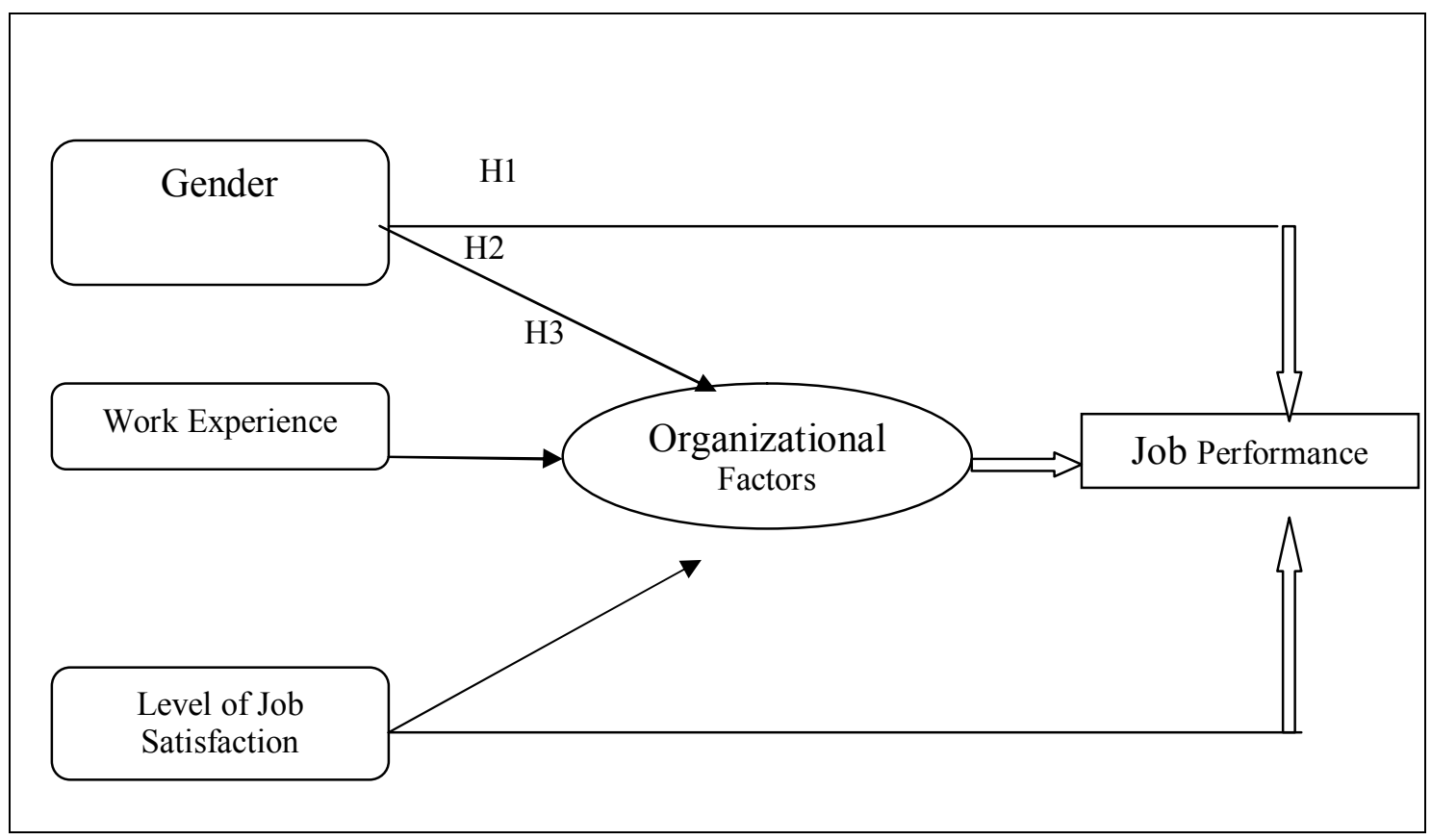

Figure 1. The Theoretical Framework

\section{Hypotheses}

Based on the literature review and theoretical framework, the following hypotheses were proposed

H1: gender has a positive and significant influence on the organizational factors that affect job performance

H2: work experience has a positive and significant influence on the organizational factors that affect job performance

H3: level of job satisfaction has a positive and significant influence on the organizational factors that affect job performance

\section{Method}

\subsection{Questionnaire Design and Data Collection}

To test the proposed given hypotheses, quantitative approach was mainly applied and a questionnaire survey was used to collect data. All questionnaire items were developed with five-point Likert-scale. accordingly, the scores of responses to each statement were calculated according to the five-point Likert on which strongly agree $=5$ points, agree $=$ 
4 points, uncertain $=3$ points, disagree $=2$ points, and strongly disagree $=1$ point.

\subsection{Sample and Procedure}

The target population of this study was the Entry-level employees who working in three star hotels in different departments in Greater Cairo. The reason to focus on the Three-star hotels that these hotels' category has not been given enough attention by the upper hospitality management. As well as it did not receive enough attention from the researchers who did not focus their scientific research on its shortcomings.

The data was collected from 7 hotels (Constituting a representation of 20\%). According to The Egyptian Hotel Guide (2015), there are 36 three-star hotels in Greater Cairo with a total of 5410 employees. The reason of choosing this distention is that Greater Cairo is considered appropriate for a study of factors affecting line staff job performance in three-star hotels.

The data was collected from these hotels with convenience sampling method, in which 541 questionnaires for the entry-level employees were distributed. Questionnaires were delivered directly to target respondents with help and permission of the human resources managers in each hotel. The response rate was $66 \%$, i.e. 358 questionnaires were valid to the analysis of the study.

Questionnaire consists of two major sections: A and B. Section A is concerned about the respondent's level of job satisfaction and biographical information such as gender (male or female), work experience.

Section B consists of 30 questions including in six independent variables as the following:-

1- Managerial Standards (including five sub-items)

2- Commitment (including five sub-items)

3- Training and development (including five sub-items)

4- Empowerment (including five sub-items)

5- Promotional fairness (including five sub-items)

6- Salaries and compensations (including five sub-items) 


\subsection{Validity of the Instruments}

Validity is the degree of how much outcomes acquired from the investigation of the information represent the phenomenon under examination (Mugenda and Mugenda, 2008). Such information is a genuine

impression of the factors; at that point, the surmising in light of such information will be exact and significant. The examination received the substance validity by discussing the questionnaires and with the experts if hospitality industry and academic professors' to ascertain the validity of the instruments".

A pilot test of the survey was controlled 28 line staff employees that were not some portion of the frame sample for this study. This gathering of respondents was told to react to questionnaire items and show their concerns with respect to any of the things. In addition, data were analyzed to measure the reliability and quality of the instrument. Contribution from the pilot contemplate showed that questionnaire was clear and simple to take after.

\subsection{Data Analysis:}

The quantitative data were entered and analyzed using the SPSS (Statistical Package for Social Sciences version 19.0), and the level of significance $(\alpha)$ was set at 0.05 . Descriptive and inferential statistical tests were used. Hypothesis were tested and analyzed by using one wayMANOVA, and regression analysis

\section{Results}

\subsection{Reliability Analysis}

Reliability is a measure of how much research instruments yield reliable outcomes after rehashed trials. It is essentially how much test scores are free from estimation of errors (Mugenda and Mugenda, 2008; Gall et al., 2006). The test-retest method was employed to establish the reliability of the questionnaires. This was done by administering the same instrument to the same group of respondents more than once. (Gregory, 2014). Therefore, the 
reliability of this portion of the instrument was determined. A Cronbach's alpha of 0.71 was found from the pilot test, indicating that the instrument was reliable with a high degree of internal consistency. All the variables are considered as good reliability as shown below in table (1)

Table (1)

Reliability Analysis

\begin{tabular}{|c|c|}
\hline Variables & Cronbach's Alpha \\
\hline Managerial Standards & .701 \\
\hline Commitment & .717 \\
\hline Training and development & .725 \\
\hline Empowerment & .702 \\
\hline Promotional fairness & .721 \\
\hline Salaries and compensations & .749 \\
\hline
\end{tabular}

\subsection{Testing of Hypotheses}

\subsubsection{The effect of gender and work experience on the organizational}

\section{factors that affecting job performance}

H1: gender has a positive and significant influence on the organizational factors that affecting job performance

H2: work experience has a positive and significant influence on the organizational factors that affecting job performance

The research hypotheses indicate that the analysis has multiple independent variables gender (male/female and work experience) and multiple dependent variables (managerial standards, commitment, training and development, empowerment, promotional justices, salaries and compensations). Thus, one way- MANOVA has been used as the best method analysis tool for multiple variables. 


\section{Factors Affecting Hotelier Job Performance - A study of Entry Level Position Staff in Three-Star Hotels}

\begin{tabular}{|c|c|c|c|c|c|}
\hline \multicolumn{6}{|c|}{$\begin{array}{c}\text { Table (2) } \\
\text { Multivariate Tests }\end{array}$} \\
\hline $\begin{array}{l}\text { independent } \\
\text { variables }\end{array}$ & & $\begin{array}{l}\text { Wilks' } \\
\text { Lambda }\end{array}$ & F. & P. Value & $\begin{array}{c}\text { Observed } \\
\text { Power }\end{array}$ \\
\hline \multirow{2}{*}{ GENDER } & Male & 919 & 2.437 & .004 & .971 \\
\hline & Female & .957 & 2.521 & .021 & .839 \\
\hline $\begin{array}{c}\text { WORK } \\
\text { EXPERIENCE }\end{array}$ & & .969 & .603 & .900 & .426 \\
\hline
\end{tabular}

Table (2) shows the overall model tests of significance. The results reveal that male and female gender, has a significant influence on the dependent variables, Wilk's (.91, .95), F (2, 437, 2.521), $\mathrm{p}<.004, .021$, and multivariate $(.97, .83)$, respectively. While, work experience has no significant influence on the dependent variables. This significant $\mathrm{F}$ indicated that there are significant differences between the gender groups on a linear combination of the six dependent variables (managerial standards, commitment, training and development, empowerment, promotional fairness, salary and compensation, and last appraisal category).

The multivariate (.97 and .83) for gender indicates that approximately $83 \%$ of "multivariate variance" of the dependent variables is associated with the female factor, and approximately $97 \%$ of "multivariate variance" of the dependent variables is associated with the male factor. The previous result indicates that male gender are more strongly affected in relation to the six organizational factors than the female gender. Therefore, each of these variables is expected to have a significant effect on one or more dependent variables.

Table (3) shows the results of the MANOVA. The MANOVA extracts the roots of the dependent variables and then basically examines factorial ANOVAs on the root of the dependent variables for all the independent variables. 
Table (3)

Tests of Between-Subjects Effects

\begin{tabular}{|c|c|c|c|c|c|c|c|}
\hline Source & $\begin{array}{l}\text { Dependent } \\
\text { Variable }\end{array}$ & $\begin{array}{l}\text { Type III } \\
\text { Sum of } \\
\text { Squares }\end{array}$ & Df & $\begin{array}{c}\text { Mean } \\
\text { Square }\end{array}$ & $\mathrm{F}$ & Sig. & Observed Power \\
\hline \multirow{6}{*}{ MALE } & MANAGERIAL & 3.707 & 1 & 3.707 & .352 & .553 & 091 \\
\hline & COMMITMENT & 107.510 & 1 & 107.510 & 9.063 & .003 & .851 \\
\hline & TRAINING & 5.978 & 1 & 5.978 & .357 & .550 & .092 \\
\hline & EMPOWERMENT & 69.546 & 1 & 69.546 & 4.232 & .040 & .536 \\
\hline & SALARIES & 97.121 & 1 & 97.121 & 8.128 & .005 & .811 \\
\hline & PROMOTION & 60.744 & 1 & 60.744 & 5.037 & .025 & .610 \\
\hline \multirow{6}{*}{ FEMALE } & MANAGERIAL & 56.169 & 2 & 28.084 & 2.666 & .071 & .527 \\
\hline & COMMITMENT & 77.109 & 2 & 38.555 & 3.250 & .040 & .617 \\
\hline & TRAINING & 31.817 & 2 & 15.908 & .951 & .387 & .215 \\
\hline & EMPOWERMENT & 93.441 & 2 & 46.721 & 2.843 & .060 & .556 \\
\hline & SALARIES & 122.984 & 2 & 61.492 & 5.146 & .006 & .824 \\
\hline & PROMOTION & 156.548 & 2 & 78.274 & 6.490 & .002 & .905 \\
\hline \multirow{6}{*}{$\begin{array}{l}\text { WORK } \\
\text { EXPERIENCE }\end{array}$} & MANAGERIAL & 7.674 & 3 & 2.558 & .243 & .866 & .096 \\
\hline & COMMITMENT & 23.141 & 3 & 7.714 & .650 & .583 & .187 \\
\hline & TRAINING & 48.240 & 3 & 16.080 & .961 & .411 & .262 \\
\hline & EMPOWERMENT| & 19.499 & 3 & 6.500 & .395 & .756 & .128 \\
\hline & SALARIES & 31.233 & 3 & 10.411 & .871 & .456 & .240 \\
\hline & PROMOTION & 5.260 & 3 & 1.753 & .145 & .933 & .077 \\
\hline
\end{tabular}

The MANOVA shows that the male gender has a significant influence on four of organizational factors that affect the employee performance. These factors explained as commitment $(p=0.003)$, empowerment $(p=0.040)$, promotion justices $(\mathrm{p}=0.025)$, and salary and compensation $(\mathrm{p}=0.005)$. On other hand, the given observed power re-arrange the importance of the significant variables from higher priority to the lower showing that the commitment is the higher variable (.851) following by salaries (.811), 


\section{Factors Affecting Hotelier Job Performance - A study of Entry Level Position Staff in Three-Star Hotels}

promotion (.611) and the lower variable is the empowerment (.536). In addition, female age has a significant influence on three of organizational factors that affect the employee performance. These factors displayed as: promotion justices $(p=0.002)$; commitment $(p=0.040)$; salary and compensation $(\mathrm{p}=0.006)$.

The given observed power re-arranged the importance of the significant variables from higher priority to the lower showing that the commitment is the higher variable promotion (.905) following by salaries (.824), and the lower variable is the empowerment (.617), Thus H2 "Gender has a positive and significant influence on the organizational factors that affecting job performance has been confirmed.

On contrary, work experience has no significant influence on all the organizational factors that affect the employee performance. Thus, hypothesis 3 , i.e. "work experience has a positive and significant influence on the organizational factors that affecting job performance" was rejected.

\subsubsection{The effect of job satisfaction on the organizational factors that affecting job performance}

H3: level of job satisfaction has a positive and significant influence on the organizational factors that affect job performance

Table (4)

Model Summary

Dependent Variable: job satisfaction

\begin{tabular}{|c|c|c|c|c|c|c|c|c|c|c|}
\hline \multirow[b]{2}{*}{$\begin{array}{l}\text { Mode } \\
1\end{array}$} & \multirow[b]{2}{*}{$\mathrm{R}$} & \multirow[b]{2}{*}{$\begin{array}{c}\mathrm{R} \\
\text { Squar } \\
\mathrm{e}\end{array}$} & \multirow[b]{2}{*}{$\begin{array}{c}\text { Adjuste } \\
\text { d R } \\
\text { Square }\end{array}$} & \multirow[b]{2}{*}{$\begin{array}{l}\text { Std. } \\
\text { Error of } \\
\text { the } \\
\text { Estimat } \\
\text { e }\end{array}$} & \multicolumn{5}{|c|}{ Change Statistics } & \multirow[b]{2}{*}{$\begin{array}{c}\text { Durbin } \\
- \\
\text { Watso } \\
\mathrm{n}\end{array}$} \\
\hline & & & & & $\begin{array}{c}\mathrm{R} \\
\text { Square } \\
\text { Chang } \\
\mathrm{e}\end{array}$ & $\begin{array}{c}\text { F } \\
\text { Chang } \\
\text { e }\end{array}$ & $\begin{array}{c}\mathrm{df} \\
1\end{array}$ & $\mathrm{df} 2$ & $\begin{array}{c}\text { Sig. F } \\
\text { Chang } \\
\text { e }\end{array}$ & \\
\hline 1 & $\begin{array}{r}.252 \\
\mathrm{a}\end{array}$ & .063 & .047 & .73747 & .063 & 3.952 & 6 & $\begin{array}{r}35 \\
1\end{array}$ & .001 & 2.002 \\
\hline
\end{tabular}

Table (4) shows the model summary and overall fit statistics. The results indicate that the adjusted $\mathrm{R}^{2}$ of the model is 0.63 with the $\mathrm{R}^{2}=.47$. This means that the linear regression explains $63 \%$ of the variance in the data. 
While, the remaining of $37 \%$ are describable by other factors. The adjusted $\mathrm{R}^{2}$ corrects the $\mathrm{R}^{2}$ for the number of independent variables in the analysis, thus it helps detect over-fitting, because every new independent variable in a regression model always explains a little additional bit of the variation, which increases the $\mathrm{R}^{2}$. The Durbin-Watson $\mathrm{d}=2.002$ is between the two critical values of $1.5<\mathrm{d}<2.5$, therefore we can assume that there is no first order linear auto correlation in the data. The F-test shows the predictors (managerial standards, commitment, training and development, empowerment, promotional justices, salaries and compensations) simultaneously influence employee job performance.

Table (5) indicates that managerial standards, commitment, and promotion variables have no partial effect on employee performance. While training, empowerment, and salaries have partial effect on employee performance, the results reveals that the linear regression analysis for salaries variable estimates the linear regression function to be $\mathrm{y}=2.332+.029 * \mathrm{x}$. This means that an increase in one unit of salaries variable results in an increase of " $29 \%$ "of staff performance.

Table (5)

Coefficients

Dependent Variable: job satisfaction

\begin{tabular}{|c|c|c|c|c|c|c|}
\hline \multirow{2}{*}{\multicolumn{2}{|c|}{ Model }} & \multicolumn{2}{|c|}{$\begin{array}{c}\text { Unstandardized } \\
\text { Coefficients }\end{array}$} & \multirow{2}{*}{$\begin{array}{c}\begin{array}{c}\text { Standardized } \\
\text { Coefficients }\end{array} \\
\text { Beta } \\
\end{array}$} & \multirow[b]{2}{*}{$\mathrm{t}$} & \multirow[b]{2}{*}{ Sig. } \\
\hline & & $\mathrm{B}$ & Std. Error & & & \\
\hline \multirow[t]{7}{*}{1} & (Constant) & 2.332 & .331 & & 7.043 & .000 \\
\hline & Managerial & .004 & .014 & .015 & .259 & .796 \\
\hline & Salaries & .029 & .014 & .134 & 2.045 &. .332 \\
\hline & Training & .042 & .010 & .230 & -4.099 & .000 \\
\hline & Empowerment & .025 & .010 & .136 & 2.416 & .016 \\
\hline & Commitment & -.013 & .013 & -.063 & -.972 & .042 \\
\hline & Promotion & -.001 & .012 & -.005 & -.086 & .932 \\
\hline
\end{tabular}

The analysis for the training variable estimated that the linear regression function to be $\mathrm{y}=2.332+.042 * \mathrm{x}$. This means that an increase in one unit of training variable results in an increase of " $42 \%$ " on staff performance. For the last significant variable (empowerment), the linear 


\section{Factors Affecting Hotelier Job Performance - A study of Entry Level Position Staff in Three-Star Hotels}

regression function to be $\mathrm{y}=2.332+.025^{*} \mathrm{x}$. This means that an increase in one unit of empowerment variable results in an increase of " $25 \%$ " of staff performance.

Table (5) also includes the Beta weights. Beta weights are the standardized coefficients and they allow comparison of the size of the effects of different independent variables if the variables have different units of measurement. Since we have multiple independent variables in the analysis, the Beta weights compare the relative importance of each independent variable in standardized terms. We find that training has a higher impact than empowerment, and salaries (beta $=.234$, beta $=.136$ and beta $=.134$ ). Thus, we can accept $\mathrm{H} 4$, i.e." "level of job satisfaction has a positive and significant influence on the organizational factors that affecting job performance".

Based on the previous results, Table 13 shows the results of hypotheses testing.

Table 6

The Results of Hypothesis Testing

\begin{tabular}{|c|l|c|}
\hline & \multicolumn{1}{|c|}{ Hypothesis } & Result \\
\hline$H 1$ & $\begin{array}{l}\text { Gender has a positive and significant influence on the } \\
\text { organizational factors that affecting job performance }\end{array}$ & acceptance \\
\hline$H 2$ & $\begin{array}{l}\text { Work experience has a positive and significant } \\
\text { influence on the organizational factors that affecting } \\
\text { job performance }\end{array}$ & acceptance \\
\hline$H 3$ & $\begin{array}{l}\text { Level of job satisfaction has a positive and significant } \\
\text { influence on the organizational factors that affect job } \\
\text { performance }\end{array}$ & acceptance \\
\hline
\end{tabular}

\section{Discussion}

This study aimed to explore the factors affecting staff job performance in three-star hotels in Greater Cairo, Egypt. Based on the literature discussed, 
six factors considered the vital components influence the employees' performance.

The results of MANOVA analysis in this study provide support for the significant effect differences among the gender groups on a linear combination of the six dependent variables (managerial standards, commitment, training and development, empowerment, promotional fairness, salary and compensation, and last appraisal category).

The multivariate (.97 and .83$)$ for gender indicates that approximately $83 \%$ of "multivariate variance" of the dependent variables is associated with being female, and approximately $97 \%$ of multivariate variance of the dependent variables is associated with being male. The previous result indicates that men are more strongly affected with the six organizational factors more than women. Therefore, each of these variables is expected to have a significant effect on one or more dependent variables

Being male has a significant influence on four of organizational factors that affect the employee performance. These factors explained as commitment $(p=0.003)$, empowerment $(p=0.040)$, promotion justices $(p=$ $0.025)$, and salary and compensation $(p=0.005)$. On other hand, the given observed power re-arrange the importance of the significant variables from higher priority to the lower showing that the commitment is the higher variable (.851) following by salaries (.811), promotion (.611) and the lower variable is the empowerment (.536),

Being female has a significant influence on three of organizational factors that affect the employee performance. These factors displayed as: promotion justices $(p=0.002)$; commitment $(p=0.040)$; salary and compensation $(p=0.006)$. In addition, the given observed power re-arrange the importance of the significant variables from higher priority to the lower showing that the commitment is the higher variable promotion (.905) following by salaries (.824), and the lowest variable is empowerment (.617). While, work experience has no significant influence on all the organizational factors that affect the employee performance.

The result of regression indicates that the adjusted $\mathrm{R}^{2}$ of the model is 0.63 with the $\mathrm{R}^{2}=.47$. This means that the linear regression explains $63 \%$ of the variance in the data. While, the remaining of $37 \%$ are describable by other factors. The adjusted $\mathrm{R}^{2}$ corrects the $\mathrm{R}^{2}$ for the number of independent variables in the analysis, thus it helps detect over-fitting, because every new 


\section{Factors Affecting Hotelier Job Performance - A study of Entry Level Position Staff in Three-Star Hotels}

independent variable in a regression model always explains a little additional bit of the variation, which increases the $\mathrm{R}^{2}$. The Durbin-Watson $d=2.002$ is between the two critical values of $1.5<\mathrm{d}<2.5$, therefore it can be assumed that there is no first order linear autocorrelation in the data. The F-test shows the predictors (managerial standards, commitment, training and development, empowerment, promotional justices, salary and compensation) simultaneously influence employee job performance

In addition, managerial standards, commitment, and promotion variables have no partial effect on employee performance. While training, empowerment, and salaries have partial effect on employee performance, the results reveals that the linear regression analysis for salaries variable estimates the linear regression function to be $\mathrm{y}=2.332+.029 * \mathrm{x}$. This means that an increase in one unit of salaries variable results in an increase of $29 \%$ of staff performance. The analysis for the training variable estimated that the linear regression function to be $\mathrm{y}=2.332+.042 * \mathrm{x}$. This means that an increase in one unit of training variable results in an increase of $42 \%$ of staff performance. For the last significant variable (empowerment), the linear regression function to be $\mathrm{y}=2.332+.025^{*} \mathrm{x}$. This means that an increase in one unit of empowerment variable results in an increase of $25 \%$ of staff performance.

The results presented previously reflect theoretical contributions to knowledge and indicate several important implications for theory and research on the organizational factors staff performance. Although previous studies have tended to adopt and measure one of the two dimensions of organizational factors that affect employee job performance either psychological performance or structural performance on job satisfaction in a western context, this study is one of the first studies that attempts to adopt and measure the six main dimensions of organizational factors on employee performance in a non-western context. In addition, the results indicated that men are more sensitive to the organizational factor than women, as well as job performance scale with six dimensions are valid and reliable among employees working in three-star hotels in Greater Cairo. 


\section{Conclusion}

Entry-level staff performance is considered to be one of the most important factors affecting the overall hospitality performance and the success of the organization in the competitive market and providing high level of service quality. The main purpose of this study is to analyze the factors affecting employee performance at their work. Through the data analysis, training, empowerment, and salaries dimensions have partial effect on the employees' performance rather any other factors. This finding may be generalized to other hotel categories; the employees' respondents in this study may have similar perceptions with the employees who work in four and five star hotels in other cities of Egypt.

Furthermore, this study helps managers about how develop and enhance the efficiency and effectiveness of their staff. Some other factors can also be taken to enhance the employee job performance, which can be further studied like turnover, satisfaction, teamwork, job security, creativity.

\section{References}

Adeyinka, M., Allen, R. \& Arthur, J.B. (2007). Effects of Human Resource

Systems on Manufacturing, Performance, and Turnover. Academy of

Management Journal, Vol. 37, pp.67-87.

Aguinis, H. (2013). Performance Management.3rdEdition, Upper Saddle

River, NJ, Pearson Education Inc. ISBN-13:0780132556385

Albattat, A.R.S., Som, A.P.M. (2013). Employee Dissatisfaction and

Turnover Crises in the Malaysian Hospitality Industry. International

Journal of Business and Management, 8 (5): 62-71.

Anil Kumar, K. S., Ravindranath, Badi (2012). Effect of Mentoring on

Employee Empowerment in Management Institutes. Journal of

Advances in Management, Dec 2012, Vol.5(12), p 32.

Blanchard, P.(2012).Organizational management behavior. 10th editions.

Translated by Kabiri, Gh, Tehran, Jehad daneshgahi institute. ISBN-10:

0132556405

.Braimah. M, (2016). Internal marketing and employee commitment in the hospitality industry. African Journal of Hospitality, Tourism and Leisure Volume 5 (2) - (2016)ISSN: 2223-814X Copyright: (C) 2016 AJHTL Open Access- Online @ http//: www.ajhtl.com

Cascio, W. F. (2015). Managing human resources: Productivity, quality of work life, profits. 10 editions. New York: McGraw-Hill. ISBN-10: 0078112958 


\section{Factors Affecting Hotelier Job Performance - A study of Entry Level Position Staff in Three-Star Hotels}

Colquitt, J., Lepine, J. \& Wesson, M. (2014). Organizational Behavior: Improving

Performance and Commitment in the Workplace. New York, NY: McGraw-Hill.

Elnaga, A. \& Imran, A. (2013). The Effect of Training on Employee Performance. European Journal of Business and Management, Vol.5, No.4, pp.137-147.

Gall, M. D., Gall, J. P., \& Borg, W. R. (2006). Educational research: An introduction (8th ed.). Pearson Education Inc. ISBN-10: 0205488498

Gregory, R.J. (2014) Psychological Testing: History, Principles and Applications. (8th ed.). Allyn and Bacon: Boston

Kahya, E. ( 2009). The effects of job performance on effectiveness. International Journal of Industrial Ergonomics, 39, 96-104.

Kim, T.T. \& Lee, G. (2013). Hospitality employee knowledge-sharing behaviors in the relationship between goal orientations and service innovative behavior. International Journal of Hospitality Management, 34, 324-337.

Macky,K.,\& Johnson, G. (2000). The strategic Management of Human Resources in New Zealand. Auckland, New Zealand: Irwin/McGrawHill

.Mondy, W. \& Noe, R. (2015). Human Resources Management. 14th Edition. Pearson Education Inc. ISBN-10: 0133848809

Motowildo, S. J. (2003) Job Performance. In W.C. Borman, D.R. llgen, \& R. J. Klimoski (Ed.), Handbook of Psychology (vol. 12, Industrial/ Organizational Psychology). 39-53. New York: Wiley.

Moulder, E. (2011). Performance Appraisals for local government employees: Programs and Practices. Washington: D.C

Mugenda, O.M and Mugenda, A.G (2008) Research Methods, Quantitative \& Qualitative Approaches, Acts Press, Nairobi

Murphy, B. (2015), The Impact of Reward Systems on Employee Performance. Master Thesis. Dublin Business School. p23

Mwita, J. I. (2000). "Performance management model: A systems-based approach to public service quality". International Journal of Public Sector Management. Vol 13, 19-37.

Netke, D. M. (2013). Role of manager in employee's motivation. Journal of Golden Research Thoughts, Vol. 2 Issue 10, 1-3. doi:10.9780/22315063 
Raja, A. G. K., Furqan, A. K. \& Muhammad, A. K. (2011). Impact of Training and Development on Organizational Performance. Global Journal of Management and Business Research, Vol.11, No.7.pp.63-68.

Randell, F. (2014). Issues and Challenges in the Practice of Performance Appraisal Activities in the 21 st Century. International Journal of Education and Research 1 (4), 1-8.

Reena, A. \& Ahmed, M.S. (2009). The Impact of Reward and Recognition Programs on Employee"s Motivation and Satisfaction: An Empirical Study. International Review of Business Research Papers, Vol.5, No.4, pp.270-279.

Rudman, R. (2003). Human Resources Management in New Zealand. Auckland: Pearson Education New Zealand Limited.

Rynes, S.L., Gerhart, B.S. \& Minette, K.A. (2004).The Importance of Pay in Employee Motivation: Discrepancies between What People say and What they Do. Human Resource Management, Vol.43, No.4, pp.381394.

Sandler.C \& Keefe. J (2004) performance appraisal phrase book, Published by Adams Media, an F+W Publications Company.57 Littlefield Street, Avon, MA 02322 U.S.A., ISBN 10: 1-58062-940-7

Sekyi, E., Ama, N. \& Joe,F. (2016). Analyzing the Factors Influencing Employee Loyalty in the Hotel Industry in Takoradi, Ghana. Journal of Tourism, Hospitality and Sports. ISSN (Paper) 2312-5187 ISSN (Online) 2312-5179 An International Peer-reviewed Journal Vol.18, 201644

Society for Human Resource Management (SHRM). (2013). Employee Job Satisfaction and Engagement: The Road to Economic Recovery.

Swarnalatha C. and Sureshkrishna G. (2014). A Study on Job Stress, Job Performance and Employee Job Satisfaction among Female Employees of Automotive Industries in India. Australian Journal of Basic and Applied Sciences, Vol. 8, No. 1, pp. 469-472.

Taiwo, A. S. (2010). The influence of work environment on workers' productivity: A case of selected oil and gas industry in Lagos, Nigeria. African Journal of Business Management, 4(3), pp. 299-307.

Tetteh, E. K., Asiedu, C., Odei, G. A., Bright-Afful, C., Akwaboah, L. (2012). Work Environment and Its Impact on Employee's Performance (A case study of Produce Buying Company, Kumasi). (Published final year project). Christian Service University College.

Van De Voorde, K., \& Beijer, S. (2014). The role of employee HR attributions in the 
relationship between high-performance work systems and employee outcomes. Human Resource Management Journal, 25(1), 62-78. doi: $10.1111 / 1748-8583.12062$

Werner, J. M. (2000) Implications of OCB and contextual performance for human resource management. Human Resource Management Review, 10(1): 245-261. 